\title{
Comparative analysis of the sectoral structure of the gross regional product of macroregions of the Russian Federation
}

\author{
Elena G. Russkova \\ Volgograd State University, \\ Institute of Economics and Finance, \\ Chair of Economic Theory, \\ World and Regional Economics \\ Volgograd, Russia \\ russkovaeg@volsu.ru
}

\author{
Oksana Yu. Vatyukova \\ Volgograd State University, \\ Institute of Management and Regional Economics \\ Chair of Applied Informatics, \\ Mathematical Methods in the Economics, \\ Volgograd, Russia \\ vatukova_o_u@volsu.ru
}

\author{
Svetlana E. Reznichenko \\ Rostov State Economic University, \\ Chair of Economic Theory, \\ Rostov-on-Don, Russia \\ reznichenko@rsue.ru
}

\begin{abstract}
The article analyses the sectoral structure of the gross domestic (regional) product of the macroregions of the Russian Federation existing in the form of federal districts. The goal of the given research consists in the identification of macro economic tendencies in the economy of the Russian Federation on the basis of the comparative analysis of the sectoral structure of the gross domestic (regional) product of macroregions. The analysis of the importance of the regional shifts in the structure of the GDP in the section of the types of the economic activity was made. For this goal the coefficients of the irregularity of the distribution of the gross domestic (regional) product in groups of industries (sectors) and the integral coefficient of structural shifts by $K$. Gatev were calculated which showed that some changes existed in the structure of industries of the gross domestic (regional) product but they were insignificant. The problems engendering the differences in the numeral values of the mentioned index are identified. The potential ways of their solution at macro and meso levels of the economic system of the Russian Federation are suggested.
\end{abstract}

Keywords - gross regional product, industrial structure, comparative analysis of the GDP (regional), coefficients of the inequality of the distribtuion of the GDP (regional) in groups of industries, integral coefficient of structural shifts by K. Gatev, macroregion

\section{INTRODUCTION}

A system of the coefficients among which the main is the gross domestic (regional) product is used to characterize the level of social and economic development of a macroregion. The gross regional product characterizes the economic activity of a region. It presents the gross added value created by the economic residents of a region which is calculated as the difference between the output and the intermediate consumption of goods and services in current basic prices and in constant prices.

The index of the gross regional product (GRP) is close in content to the ratio of the gross domestic product (GDP) but there is a considerable difference between them. The sum of the gross regional product calculated taking the data of all the regions does not coincide with the gross domestic product of Russia as the first ratio does not include the following constituents: the gross added value of the non market collective services provided by state establishments to the society in the whole (national defense and state administration); services of financial intermediaries whose activity is not limited by the borders of a separate region; services to non residents in foreign trade and other services (both market and non market) the information about which is not available at the regional level.

The GDP and GRP in market prices differ by the value of the taxes on exports and imports as the specificity of the calculation of these types of taxes does not allow distributing them completely between specific regions [3]. The value of the gross regional product is an objective indicator of the contribution of every region into the development of the national economy. In 2016 the summary gross regional product made up about $80 \%$ of the Russian GDP and in 2010 it was $69 \%$ (calculated by the author on the basis of the data [1]).

In order to determine the vector of the development of the economy of the macroregion it is important to analyze the 
dynamics of the sectoral structure of its gross regional product as it is the result of the functioning of all its industries within a definite territory. The analysis of the sectoral structure of the gross regional product of one macroregion can display its specialization, differentiation, internal absolute and relative changes but for the understanding of a general tendency of the macroeconomic development it is indispensable to compare the industrial structure of the gross regional product of the regions.

The problems of the industrial structure of the gross regional product were analyzed in the papers of both domestic and foreign scientists: A. Granberg [4], V. Butov, V. Ignatov [5], O. Litovka [6], L. Solanko [7], D. Berkowitz and D.DeJong [8], R. Arend [9], V. Popov [10] and others.

The goal of the given research is the identification of macroeconomic tendencies in the industrial (sectoral) structure of the economy of the Russian Federation on basis of the comparative analysis of the industrial structure of the gross regional product of macroregions. The study of interregional differences is important for the development of strategies of economic and social regions of macroregions, for the identification of their realization and for a consequent analysis of the productivity.

Due to territorial expansion (scale) of the Russian Federation (17,1 million square kilometers) [1] a considerable differentiation of the regions upon the level of social and economic development is observed. In accordance with the Decree of the President of the Russian Federation dated May, 132000 № 849 in Russia seven federal districts were formed: Central Federal District, Northwestern Federal District, Southern Federal District, Volga Federal District, Ural Federal District, Siberian Federal District, Far Eastern Federal District. Since January 2010 the North Caucasian Federal District was isolated from the Southern Federal District and in 2014 Crimea and the city of Sevastopol were included into the Southern Federal District. The federal districts have a specific state importance for the solution of national tasks, for the strengthening of the common economic and political space of Russia.

\section{MATERIALS AND METHODS (MODEL)}

For the provision of the reliability and consistency of the results of the research the economic and statistical methods are used which will allow constructing the models of the growth of the national economy on the basis of use of various quantitative indices. However such an approach will not allow controlling the qualitative changes taking place in the growth of the object which are presented by sectoral shifts at the level of regions and macroregions.

The empirical basis of the research are presented by the data of the Federal Service for State Statistics, expert assessments and calculations of the researchers published in public sources, normative and legal acts of federal and regional importance.

In official publications for the assessment of the gross regional product various methods are used: method of direct reassessment, method of deflating, method of extrapolation [1].

For the assessment of the gross regional product in the given research the elements of economic and statistical methods were used: coefficients of the irregularity of the distribution of the gross regional product in sectoral groups; integral coefficient of structural shifts by K. Gatev.

For the analysis the time period from 2010 to 2016 was chosen in compliance with the available indices of social and economic indices of the development of the country and the regions in the official sources for the moment of research.

The gross regional product of the Russian Federation according to the data of the Federal Service for State Statistics for the analyzed period varied from $2 \%$ to $36 \%$ in 2010 and from $4 \%$ in 2010 to $35 \%$ in 2016. (Table I).

TABLE I. STRUCTURE OF THE GROSS REGIONAL PRODUCT IN MACROREGIONS OF THE RUSSIAN FEDERATION

\begin{tabular}{|l|c|c|c|c|}
\hline & $\begin{array}{c}\text { 2010, billion } \\
\text { rubles }\end{array}$ & \% & $\begin{array}{c}\text { 2016, } \\
\text { billion } \\
\text { rubles }\end{array}$ & \% \\
\hline $\begin{array}{l}\text { Gross regional product in } \\
\text { the regions within Federal } \\
\text { Districts: }\end{array}$ & 32007 & 100 & 64997 & 100 \\
\hline Central Federal District & 11405 & 36 & 22714 & 35 \\
\hline $\begin{array}{l}\text { Northwestern Federal } \\
\text { District }\end{array}$ & 3416 & 11 & 6790 & 10 \\
\hline Southern Federal District & 1995 & 6 & 4591 & 7 \\
\hline $\begin{array}{l}\text { North Caucasian Federal } \\
\text { District }\end{array}$ & 787 & 2 & 1704 & 4 \\
\hline Volga Federal District & 4923 & 15 & 9916 & 15 \\
\hline Ural Federal District & 3391 & 14 & 8980 & 14 \\
\hline Siberian Federal District & 1731 & 5 & 3550 & 5 \\
\hline $\begin{array}{l}\text { Far Eastern Federal } \\
\text { District }\end{array}$ & a. Federal Service for State Statistics. Available at: http://gks.ru \\
\hline
\end{tabular}

The sectoral structure of the gross regional product of the macroregions (federal districts) of the Russian Federation upon the types of the economic activity according to Russian National Classifier of Types of Economic Activity which is presented in Figure 1 allows assessing the changes which took place in 2010-2016.

The sectoral structure of the gross regional product shows the share of every industry in the total volume of the gross regional product. The highest rates of indices which did not change considerably in 2010-2016 were observed in the following industries:

- Processing industries amounted to $17,7 \%$ in the total volume of the GRP in 2010 and made up $17,1 \%$ in 2016 ;

- Gross and retail trade; car and consumer equipment repair made up $19,4 \%$ and $18,1 \%$ in 2010, 2016 correspondingly; 
- $\quad$ Real estate transactions made up $11,4 \%$ and 12,7 $\%$;

- Transport and communication made up $10,5 \%$ and $9,4 \%$ correspondingly;

- Extraction of mineral resources made up $10,4 \%$ and $11,2 \%$.

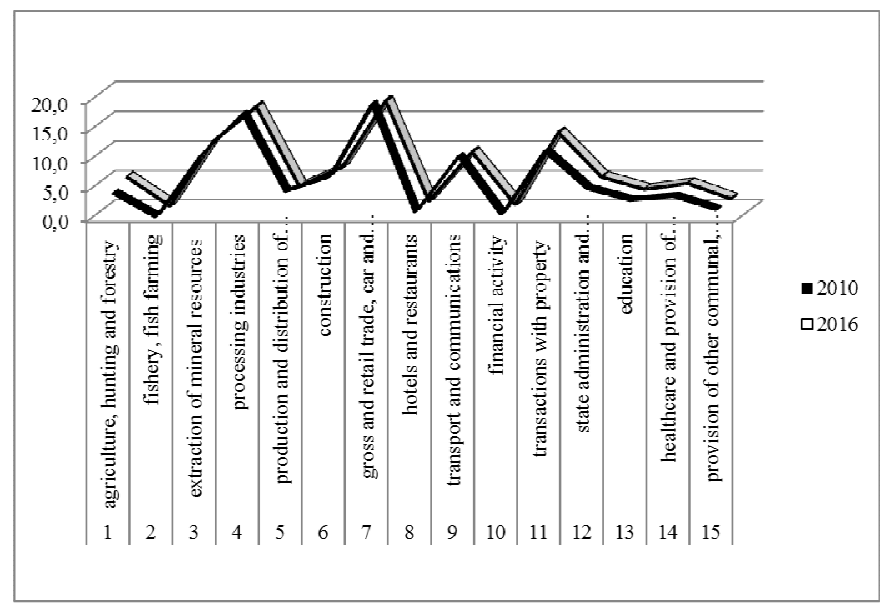

Fig. 1. Sectoral structure of the gross regional product of the Russian Federation in section of the types of economic activity (National Classifier of Types of Economic Activity) in 2010 and 2016, (\%).

The rest of the industries have an insignificant share and consequently it is worth disregard them in the research.

During the study of structural shifts in various sectors of the economy the coefficient of the irregularity of the distribution of gross regional product in groups of industries was calculated using the formula:

$$
K_{\mu p . i}=\frac{I \cdot d}{k-I} \cdot \sum_{i=1}^{k}\left(d_{i}-p\right)^{2},
$$

where $k=15$ - number of groups, $I$ - number of dominant groups where more than $60 \%$ or more units of the aggregate are presented. For the Russian Federation in the whole the number of such groups is $5, d_{i}$ is share of the group $i$ in the total aggregate, $p=\frac{1}{k}=\frac{1}{15} \approx 0,067$ is «theoretical» share under the condition of a regular distribution of the units in the aggregate [11].

In 2010 this coefficient was $K_{\mu p .(10)} \approx 0,589$, and in 2016 it was $K_{\mu p .(16)} \approx 0,476$.

Taking into account the fact that if the value of the coefficient of the irregularity is close to 1 , so the distribution of the units in the groups is irregular and the equality to zero evidences about a regular distribution. Thus the gross regional product in 2016 became less regularly distributed between industries than in 2010. The number of dominant groups did not change however their share in the structure of the gross regional product reduced a little from $69,4 \%$ in 2010 to $68,5 \%$ in 2016.

The structural changes in the economy have as a rule a positive character and can be caused by various reasons, for instance, by the state support of some industries. That is why it is important to track the character and the direction of these changes as an indicator of the efficiency of measures of the influence on economic processes.

The changes in the sectoral structure of the gross regional product of the Russian Federation according to Russian National Classifier of Types of Economic Activity in 2016 in comparison with 2010 can be seen with the help of one of the generating indices of structural shifts: integral coefficient by $\mathrm{K}$. Gatev which is calculated with the use of the formula:

$$
K_{\Gamma}=\sqrt{\frac{\sum_{i=1}^{k}\left(d_{i}-d_{0}\right)^{2}}{\sum_{i=1}^{k} d_{i}^{2}+\sum_{i=1}^{k} d_{0}^{2}}} .
$$

The coefficient by K. Gatev similar to the coefficient of the irregularity of the distribution of the gross regional product in groups of regions varies from 0 to 1 . The closer the calculated value is to 1 , the more significant the changes of the structure are in time.

When analyzing the data for 2010-2016 the coefficient by $\mathrm{K}$. Gatev made up $K_{\Gamma} \approx 0,0683$. This means that the changes in the structure of the gross regional product upon the types of economic activity made up 6,8\%. Thus from 2010 to 2016 there were no considerable changes in the sectoral structure of the gross regional product of the Russian Federation.

Thus the coefficient of the irregularity of the distribution of the gross regional product and the integral coefficient by $\mathrm{K}$. Gatev show almost similar result: from 2010 to 2016 the distribution of the gross regional product in sectoral groups was insignificant.

For the complexity of the further analysis let us classify the industries of the economy in groups:

I. Industries producing goods: heavy industry, agriculture, hunting, forestry, construction and other productions;

II. Industries delivering services: transport, communication, trade and others;

III. Industries delivering business services: healthcare, education and so on.

The industrial structure of the gross regional product of the macro regions of the Russian Federation in these groups in 2010 is shown in Figure 2.

Having compared the development of the industries in 2016 we can see that the best indices have the industries from the group I (industries producing goods) in almost all the districts except the Central Federal District. In 2010 the best ratio was observed in industries from the group II (industries delivering services). 
For group I of the industries the gross regional product in districts in 2010 varied from $28,8 \%$ to $63 \%$. The contribution of these industries into the gross regional product is more considerable than of the others and their share increases.

The share of the industries of group II in contrast decreases (the value changed from $22,4 \%$ to $43,7 \%$ ). A similar situation is also observed for group III (industries delivering business services). The share of the industries in the gross regional product is small.

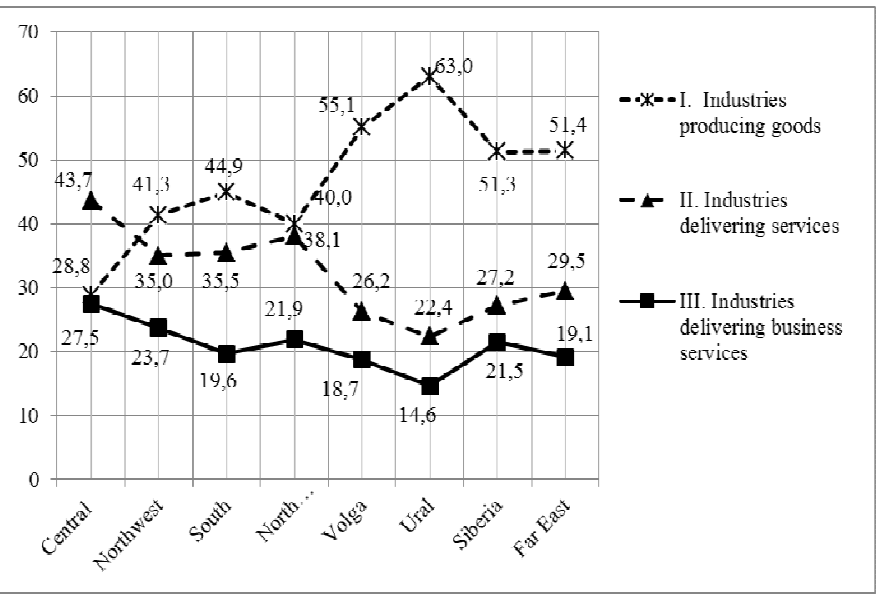

Fig. 2. Sectoral structure of the gross regional product of macroregions of the Russian Federation in groups of regions in 2010, (\%).

The sectoral structure of the Gross regional product of federal districts of the Russian Federation in 2016 is presented in Figure 3.

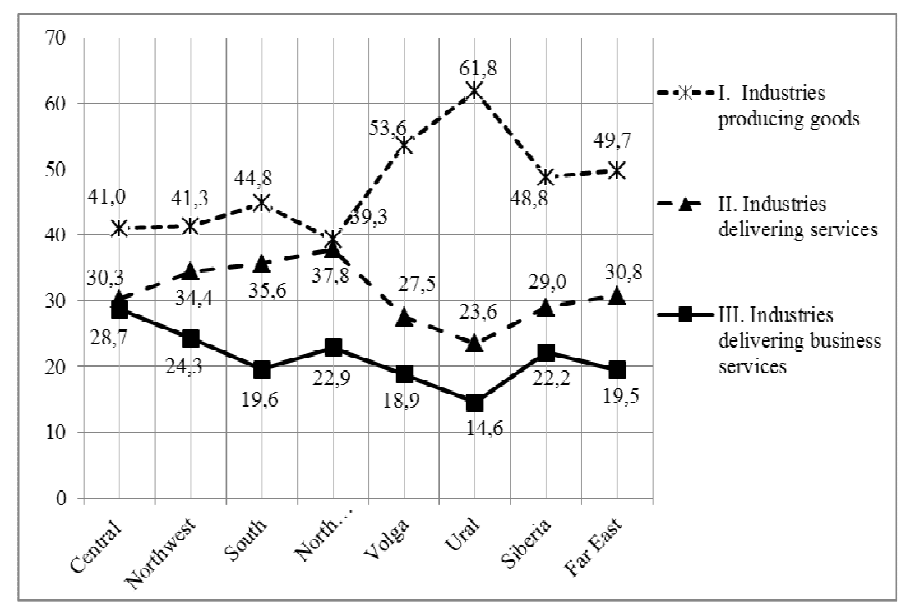

Fig. 3. Sectoral structure of the gross regional product of macroregions of Russia in groups in 2016, (\%).

The analysis of the identical index in 2016 proved that there were no significant changes in the sectoral structure of the gross regional product of macroregions of the Russian Federation in comparison with 2010.
Nevertheless in general even insignificant changes had a positive character. For instance the share of industries producing manufactured goods grew by $2 \%$. The percentage of the industries delivering services grew by $1,5 \%$. The share of industries delivering business services grew by $0,4 \%$.

In general the positive dynamics which is observed on the basis of the data mentioned above which characterize the structure of the gross regional product (as constituents of the gross domestic product) speaks about the stability of the development of industries (sectors) of the regional economy and the national economy in the whole.

\section{RESULTS AND DISCUSSION}

The government authorities of the Russian Federation face a difficult choice between the current maximization of gross indices of the efficiency of functioning of the national economy on the basis of the conservation of the existing structural proportions and regional relationships and the strategy of the increase of the quality of the economic growth as a result of structural shifts and the creation in the territory of Federal districts of highly efficient regional economic spaces. The structural shifts are determined by the goal of the reorientation of the "extracting" economy to the type of the economy producing the goods with high added value.

The main tasks in the study of the economy of macroregions are:

1) the search of the variants of use of comparative advantages of their economy for the increase of the efficiency of the national economy;

2) the increase of the complexity of the regional development, coordination of the production growth and social infrastructure for the growth of the economic efficiency and the standard of life of the population;

3 ) the search of the ways of rational production location in the territory of the regions and the creation of the interregional territorial and production complexes;

4) the harmonization of interregional transport and economic relations.

The specialization of the region denotes the prior development of the production of some types of goods or the production of definite functions taking into account the most efficient use of favourable economic conditions of the given region in order to obtain absolute or comparative advantages. The specialization of the region within the national economy is determined by means of the calculation of the share of an industry in the region and in the corresponding industry of the national economy. The calculation is carried out for the indices of the total output of production, number of the employed and the cost of the capital. Another indicator of the industrial specialization of the region is the ratio of the production of goods or the value of the fixed assets per one inhabitant of the region to a comparable value in the country.

The growth of the gross domestic product is possible at the solution of the following problems in the macroregions of the country: 
A. Growth of the competitiveness of products is possible under the following conditions:

- change of the sectoral structure of the economy due to the acceleration of the growth rate of the industries with a high share of added value;

- formation of new science intensive industries and production, flow of financial, material and labour resources into new industries.

B. Growth of the intensity of use of the intellectual component:

- growth of the productivity by means of the introduction of the innovations;

- encouragement of the demand on innovation as a stimulus for their development.

C. Development and introduction of the measures for the withdrowal of some productions from the informal sector of the economy (both in macroregions and in the country in the whole):

- $\quad$ tax amnesty;

- introduction of tax remissions for the mentioned productions within a specific period of time and so on.

Thus for the solution of the problem of the increase of the gross regional product in the specific regions and of the gross domestic product of the country a complex of economic measures of financial and fiscal character is needed

The differentiation of the regions upon the level of the gross regional product leads to the necessity of the comparison of their initial infrastructural, financial and institutional constituents for the identification of common traits and lacking elements within a regional economic system of every specific region.

This will allow identifying the reasons of regional discrepancies in numeral values of gross regional product and will suggest measures for the solution of the given problems for the expansion of the opportunities of social and economic development in both federal districts and in the country in the whole.

\section{CONCLUSION}

On the basis of the obtained results the following conclusions can be made. There were no considerable changes for the period from 2010 to 2016 in the sectoral structure of the gross regional product of the Russian Federation. The concentration of the gross regional product in the industries which are not connected with the production of the means of production shows either a complete absence of the state support of these industries or the inefficiency of the taken measures. Besides the assessment of the dynamics of the regional structure of the gross regional product in federal districts of Russia leads to the conclusion about the concentration of the gross regional product and consequently of the volume of the produced goods, volume of the delivered services, performed works in the Central Federal District. Thus it is indispensable to develop a new regional policy focused not only on the growth of quantitative indices but also on the change of qualitative characteristics of the growth due to structural changes in the industries of the economy and the increase of the economic efficiency of use of factors of production in the regions. Taking into account the existing resource and production potential of the territory it is necessary to use it reasonably and in doing so to increase the level of the development of the macroregion.

\section{References}

[1] Federal'naya sluzhba gosudarstvennoi statistiki [Federal Service for State Statistics]. Available at: http:// gks.ru. Reference date: 30.01.2018.

[2] Puti uvelicheniya VVP Rossii [Ways of increase of the GDP of Russia]. Available at: https://www.kazedu.kz/referat/116509/2/. Reference date: 15.03.2018.

[3] Fetisov G.G., Oreshin V.P. Regional'naya ekonomika i upravlenie [Regional economics and management]. - Moscow: INFRA-M Publ., 2007, 416 p.

[4] Granberg A.G. Osnovy regional'noi ekonomiki [Fundamentals of regional economics]. Moscow : GUVSHE Publ., 2001, 492 p.

[5] Ignatov V.G., Butov V.I. Regionovedenie (ekonomika i upravlenie): Uchebnoe posobie [Regional studies (economics and management): Text Edition]. Moscow: Tessa; Rostov-on-Don: «MarT» Publ., 2000, 416 p.

[6] Litovka O.P., Novikov E.A. Prirodno-resursnyi potentsial regional'nykh sotsial'no-ekonomicheskikh kompleksov [Natural and resource potential of social and economic complexes]. Leningrad: Nauka Publ., 1991, 127 p.

[7] Solanko L. An Empirical Note on Growth and Convergence Across Russian Regions. BOFIT Discussion Paper 9. Institute for Economies in Transition, Bank of Finland, Helsinki, 2003.

[8] Berkowitz D., DeJong D. Policy Reform and Growth in Post-Soviet Russia. European Economic Review, 2003, No. 47, pp. 337-352.

[9] Ahrend R. Speed of Reform, Initial Conditions, Political Orientation, or What? Explaining Russian Regions. Economic Performance. DELTA Working Paper, 2002, No. 10.

[10] Popov V. Reform Strategies and Economic Performance of Russia's Regions. 2001. Available at: http://fir.nes.ru/ vpopov/documents/Regions_Apr2000.pdf. Reference date: 30.01.2018.

[11] Eliseeva I.I., Izontov A.V., Kapralova E.B. Statistika. Uchebnik [Statistics. Text Edition]. Edited by I.I. Eliseeva, Moscow: KNORUS Publ., 2006, 552 p.

[12] Analiticheskii portal. gumanitarnye tekhnologii [Analytical portal. Humanitarian technologies]. Available at: http://gtmarket.ru/ratings/rating-countries-gdp/rating-countries-gdp-info. Reference date: 30.01.2018.

[13] Federal'naya sluzhba gosudarstvennoi statistiki [Federal Service for State Statistics]. Available at: http:// gks.ru. Reference date: 30.01.2018.

[14] Spravochnye tablitsy [Refernce tables]. Available at: http://infotables.ru/statistika/43-ekonomicheskaya-statistika-stranmira/426-struktura-vvp-stran-mira-tablitsa. Reference date: 30.01.2018.

[15] Sravnenie VVP SShA i Rossii [Comparison of Gross Domestic Product of the USA and Russia]. Available at: https://smartlab.ru/blog/419678.php. Reference date: 30.01.2018.

[16] Investitsionnyi forum: innovatsii dlya biznesa [Investment forum: innovations for business]. Available at: http://www.innovbusiness.ru/NewsAM/NewsAMShow.asp?ID=16016. Reference date: 30.01.2018.

[17] Puti uvelicheniya VVP Rossii [Ways of increase of the GDP of Russia]. Available at: https://www.kazedu.kz/referat/116509/2. Reference date: 30.01.2018. 